\begin{tabular}{l|l|l} 
Jurnal Eksplorasi Akuntansi (JEA) & $\begin{array}{l}\text { e-ISSN : 2656-3649 (Online) } \\
\text { hol. 3, No 4, November 2021, Hal 893-907 }\end{array}$
\end{tabular}

\title{
Pengaruh Kepemilikan Institusional, Komisaris Independen, Komite Audit, Pertumbuhan Penjualan, dan Leverage terhadap Manajemen Laba
}

\author{
Yola Fionita ${ }^{1 *}$, Halkadri Fitra ${ }^{2}$ \\ ${ }^{1,2}$ Fakultas Ekonomi, Universitas Negeri Padang \\ *Korespondensi: yolafionita199@,gmail.com
}

\begin{abstract}
This study aims to examine the effect to institusional ownership, independent commissioners, audit commites, sales growth, and leverage on earnings management. The population used ini this study were all manufacturing companies listed on the Indonesia Stock Exchange in 2015-2019. The sample in this study were 40 companies using purposive sampling method. Hypothesis testing in this study uses multiple linear regression analysis. The result of this study indicate that institusional ownership, audit committee, sales growth, and leverage have no effect on earnings management, while independent commissioners affect earnings management. Simultaneously institusional ownership, independent commissioners, audit committees, sales growth, and leverage affect earnings management.
\end{abstract}

Keywords: Institusional Ownership; Independent Commissioners; Audit Commites; Sales Growth; Leverage; Earnings Management.

How to cite (APA $6^{\text {th }}$ style)

Fionita, Y \& Fitra, H. (2021). Pengaruh Kepemilikan Institusional, Komisaris Independen, Komite Audit, Pertumbuhan Penjualan, dan Leverage terhadap Manajemen Laba. Jurnal Eksplorasi Akuntansi (JEA), 3 (4), 893-907.

\section{PENDAHULUAN}

Laporan keuangan merupakan sebuah sumber informasi yang biasa digunakan oleh pihak eksternal yang mempunyai kepentingan di dalam perusahaan. Penerbitan laporan keuangan bertujuan untuk memberi gambaran kepada pihak eksternal terkait dengan kondisi yang terjadi di dalam perusahaan, kondisi tersebut seperti kondisi operasional maupun kondisi finansial perusahaan. Laporan keuangan memiliki beberapa komponen salah satunya adalah laporan laba rugi. Laporan laba rugi memberikan gambaran tentang kinerja perusahaan dalam suatu jangka waktu tertentu. Penilaian terhadap kinerja yang telah dijalankan oleh perusahaan dapat tergambarkan dari laba atau rugi diperoleh perusahaan dalam suatu periode.

Dalam mencapai target laba, manajemen akan melakukan pemilihan terhadap kebijakan akuntansi tertentu sehingga nantinya laba perusahaan bisa diatur. Tindakan manajemen dalam mengatur laba dapat dikatakan sebagai istilah manajemen laba (earnings management). Menurut Sulisyanto (2018:6) manajemen laba dapat dikatakan sebagai upaya yang dilakukan oleh manajer perusahaan untuk memberi pengaruh pada informasi-informasi yang terdapat di dalam laporan keuangan dengan tujuan untuk mengelabui para stakeholder 
yang ingin mengetahui bagaimana kinerja dan kondisi di dalam perusahaan. Tindakan perusahaan yang melakukan manajemen laba dapat mengurangi kredibilitas pada laporan keuangan, dan juga menambah bias pada laporan keuangan serta dapat menganggu para pengguna laporan keuangan yang percaya pada angaka hasil rekayasa tersebut sebagai angka yang sebenarnya.

Melakukan pencegahan terhadap praktik manajemen laba, penerapan good corporate governance sangat diperlukan. Adanya good corporate governance bisa menolong para stakeholder untuk lebih percaya bahwa laporan keuangan yang disajikan oleh perusahaan terbebas dari indikasi terjadinya kecurangan (fraud).Dalam penelitian ini mekanisme good corporate governance menggunakan komponen kepemilikan institusional, komisaris independen, dan komite audit. Kepemilikan institusional yang cukup tinggi bisa meminimalisir adanya tindakan manajemen laba tergantung pada jumlah kepemilikanya, sehingga dapat memonitor pihak manajemen agar bisa mengurangi motivasi manajer dalam melakukan praktik manajemen laba (Cahyaningtyas, 2018). Selanjutnya, komisaris yang indepeden memiliki pengawasan yang baik kepada manajemen, sehingga dapat mempengaruhi kemungkinan terjadinya kecurangan dalam penyajian laporan keuangan yang dijalankan oleh manajemen, artinya apabila dewan komisaris semakin kompeten maka dapat meminimalisir terjadinya kecurangan dalam pelaporan keuangan. Selanjutnya, komite audit memiliki tugas untuk membantu dewan komisaris dalam memonitor proses pelaporan keuangan yang dilakukan oleh manajemen dalam upaya melakukan peningkatan terhadap kredibilitas laporan keuangan. Dengan dilaksanakannya audit terhadap laporan keuangan perusahaan diharapkan dapat meminimalisir terjadinya manajemen laba.

Selain kepemilikan institusional, dewan komisaris, dan komite audit, juga terdapat faktor lain yang dapat mempengaruhi manajemen laba yaitu, pertumbuhan penjualan dan leverage. Perusahaan yang mengalami pertumbuhan penjualan tinggi kemungkinan tidak termotivasi untuk melakukan tindakan manipulasi laba (Kim, et al. 2003 dalam Kadir, 2018). Begitupun sebaliknya apabila perusahaan mengalami pertumbuhan penjualan yang rendah maka bisa saja perusahaan cederung mempunyai keinginan untuk melakukan tindakan manipulasi labanya. Selanjutnya, leverage merupakan suatu rasio yang melakukan pengukuran seberapa besar perusahaan mampu dibiayai oleh hutang dengan kemampuan yang dimiliki oleh perusahaan. Apabila suatu perusahaan memiliki tingkat leverage yang tinggi biasanya memiliki motivasi dalam melakukan tindakan manajemen laba agar dapat terhindar dari perjanjian hutang.

Fenomena yang sering terjadi dan berhubungan dengan manajemen laba biasanya disebabkan karena terjadinya kesalahan ataupun ketidaktelitian dari subjek manajemen yang secara langsung ataupun secara tidak langsung dipengaruhi oleh berbagai faktor, baik faktor internal maupun faktor eksternal pada perusahaan. Hal ini didukung dengan terbongkarnya kasus manajemen laba yang banyak terjadi pada perusahaan manufaktur salah satunya perusahaan PT. Tiga Pilar Sejahtera Food Tbk (AISA) yang merupakan salah satu perusahaan manufaktur di Indonesia. Pada tanggal 26 Maret 2019, lembaga akuntan publik Ernst \& Young (EY) telah mengeluarkan audit terkait dengan soal dugaan pelanggaran yang telah dilakukan oleh manajemen lama AISA. Terdapat beberapa poin penting yang disampaikan oleh EY didalam keterbukaan informasi yaitu terkait pembanding antara data internal dengan laporan keuangan tahun 2017 yang sudah di audit. Poin-poin itu diantaranya yang pertama, terdapat dugaan overstatement sebesar Rp 4 Triliun pada akun piutang usaha, persediaan, dan aset tetap grup AISA dan sebesar Rp 662 Miliar pada penjualan serta Rp 329 Miliar pada Ebitda Entitas Food. Kedua, terdapat dugaan aliran dana sebesar Rp 1,78 Triliun dengan berbagai skema dari Grup AISA kepada pihak-pihak yang diduga terafiliasi dengan manajemen lama anatar lain dengan menggunakan pencairan pinjaman AISA dari beberapa bank, pencairan deposito berjangka, transfer dana di rekening Bank, dan pembiayaan beban 
pihak terafiliasi oleh Grup AISA. Ketiga, terkait hubungan dan transaksi dengan pihak terafiliasi, tidak ditemukan adanya pengungkapan (disclosure) secara memadai kepada para pemangku kepentingan (stakehholders) yang relevan (cnbcindonesia.com).

Penelitian ini memiliki tujuan untuk mengetahui bagaimana pengaruh dari kepemilikian institusional, komisaris independen, komite audit, pertumbuhan penjualan dan leverage terhadap manajemen laba pada perusahaan manufaktur yang terdaftar di Bursa Efek Indonesia. Pembeda penelitian yang penulis lakukan dengan penelitian sebelumnya terletak dalam periode waktu yang digunakan. Penelitian ini menggunakan periode waktu 2015 sampai dengan 2019. Penulis memilih perusahaan manufaktur sebagai subjek penelitian karena perusahaan manufaktur mempunyai resiko bisnis yang cukup besar dan less regulated, sehingga fenomena terkait dengan manajemen laba ini paling mungkin terjadi pada perusahaan manufaktur. Hal tersebut didukung oleh Astari dan Suryana (2017), yang menyatakan bahwa di dalam perusahaan manufaktur lebih banyak terdeteksi adanya praktik manajemen laba.

\section{REVIEW LITERATUR DAN HIPOTESIS}

Teori keagenan adalah teori yang menjelaskan tentang sebuah kepemilikan serta pendelegasian pengelolaan, yang melihat perusahaan sebagai sebuah hasil perjanjian atau kesepakatan antara berbagai pihak seperti manajemen, kreditur, pemegang saham, pemerintah serta masyarakat. Didalam teori agensi ini terdapat sebuah hubungan antara agen dan prinsipal. Adanya tindakan atau praktik manjemen laba bisa dijelaskan dengan menggunakan teori keagenan. Sebagai agen, manajer secara moral memiliki tanggung jawab untuk melakukan optimalisasi keutungan para pemilik (principal) dan kemudian agen juga akan mendapatkan kompensasi atau bonus sesuai kontrak yang telah disepakati.

Fahmi (2014:204), manajemen laba merupakan suatu kegiatan yang mengatur laba sesuai dengan apa yang diiinginkan oleh pihak tertentu atau terutama yang diinginkan oleh manajemen perusahaan (company management). Manajemen laba timbul disebabkan karena manejemen menginginkan sebuah manfaat tertentu secara pribadi dalam proses pelaporan keuangan, dengan memanfaatkan fleksibilitas pada pemilihan metode akuntansi dalam proses penyusunan laporan keuangan.

Good Corporate Governance merupakan sebuah strategi dalam membatasi tindakan manajemen laba dengan cara memberdayakan korporasi, baik pada perusahaan pemerintah ataupun perusahaan swasta. Menurut Muh. Arief Effendi (2016:11), Coporate governance yang baik bisa dairtikan sebagai suatu sistem yang mengelola serta mengendalikan sebuah perusahaan dalam memberikan nilai tambah bagi para stakeholder. Cahyaningtyas (2018), kepemilikan institusional adalah kepemilikan saham yang dimiliki oleh suatu instansi atau lembaga seperti bank, perusahaan asuransi, perusahaan investasi, dan perusahaan dana pensiun.

Widyaningsih (2017), menyebutkan bahwa komisaris independen adalah kedudukan terbaik dalam menjalankan fungsi monitoring agar dapat menciptakan perusahaan yang good corporate governance. Adanya komisaris independen diharapkan dapat mendorong serta menciptakan iklim yang lebih objektif, dan menempatkan kesetaraan (fairness) sebagai prinsip utama dalam melihat kepentingan para pemegang saham minoritas dan stakeholders lainnya.

Ikatan Komite Audit Indonesia (IKAI) mendefinisikan komite audit sebagai sebuah komite yang bekerja secara profesional serta independen yang pembentukannya dilakukan oleh dewan komisaris, dengan demikian tugas adari komite audit yaitu membantu serta memperkuat fungsi dewan komisaris dalam melakukan fungsi pengawasan terhadap proses pelaporan keuangan, manajemen risiko, pelaksanaan audit, serta implementasi dari corporate 
governance di perusahaan. Jumlah komite audit minimal tiga orang anggota yang berasal dari komisaris independen dan pihak luar.

Pertumbuhan penjualan memberikan gambaran tentang seberapa besar peningkatan penjualan yang akan terjadi pada perusahaan di setiap periodenya dan hal ini bisa memberikan motivasi kepada manajer untuk memperoleh laba (Sari dan Rusli, 2017). Leverage adalah sebuah rasio yang mengukur seberapa besar perusahaan dibiayai oleh hutang dengan kemampuan perusahaan yang digambarkan oleh ekuitas dan aset (Yatulhusna, 2015). Leverage digunakan di dalam perusahaan bisa saja untuk meningkatkan laba perusahaan, akan tetapi apabila terjadi sesuatu yang tidak sesuai dengan harapan, maka perusahaan bisa mendapatkan kerugian yang setara dengan preserntase laba yang diharapkan dan bisa saja lebih dari itu.

\section{Pengaruh Kepemilikan Institusional terhadap Manajemen Laba}

Investor institusional dapat dikatakan sebagai investor yang canggih (sophisticated) sehingga seharusnya investor institusional tersebut lebih dapat menggunakan informasi periode sekarang dalam memprediksi laba masa depan. Hasil penelitian Almalita (2017) menunjukkan bahwa kepemilikan institusional tidak berpengaruh terhadap manajemen laba. Hal ini disebabkan karena kepemilikan institusional sebagai pemilik sementara perusahaan lebih berfokus pada current ratio dan kepemilikan institusional juga tidak mempunyai kemampuan dalam mengendalikan manajemen sehingga tidak bisa mengurangi praktik manajemen laba. Maka hipotesis pertama dalam penelitian ini yaitu:

H1: Kepemilikan institusional berpengaruh negatif terhadap manajemen laba

\section{Pengaruh Komisaris Independen terhadap Manajemen Laba}

Komisaris independen merupakan anggota komisaris yang tidak terafiliasi dengan manajemen, anggota dewan komisaris lainnya dan pemegang saham pengendali, serta bebas dari hubungan bisnis dan hubungan lainnya yang dapat mempengaruhi kemampuannya untuk bertindak independen atau bertindak semata-mata demi kepentingan perusahaan (Almalita, 2017). Terkait dengan manajemen laba, apabila tingkat dewan komisaris independen semakin tinggi maka dapat menyebabkan semakin tinggi pula terjadinya tindakan manajemen laba. Hal ini mengindikasikan bahwa besar ataupun kecilnya komisaris independen bukan menjadi penentu utama dalam melaksanakan fungsi serta tugas dari komisaris independen tersebut karena dengan kemungkinan adanya penambahan terhadap anggota komisaris independen di dalam suatu perusahaan hanya sebagai ketentuan formal, sedangkan pemegang saham mayoritas masih memegang banyak peranan di dalam perusahaan. Dalam penelitian yang dilkaukan oleh Almalita (2017) menyatakan bahwa penambahan dalam anggota komisaris independen dimungkinkan hanya sekedar memenuhi ketentuan formal, sehingga bisa dikatakan kurang efektif di dalam mencegah terjadinya praktik manajemen laba. Maka hipotesis kedua dalam penelitian ini yaitu:

H2: Komisaris independen berpengaruh negatif terhadap manajemen laba

\section{Pengaruh Komite Audit terhadap Manajemen Laba}

Komite audit dikatakan sebagai pihak independen yang mempunyai tugas dalam melakukan pengawasan terhadap laporan keuangan perusahaan serta melakukan perbaikan apabila terdapat kesalahan. Hasil penelitian Taco dan Ilat (2016) menujukkan bahwa komite audit tidak berpengaruh terhadap manajemen laba. Dengan kata lain, besar atau kecilnya suatu ukuran komite audit tidak memiliki pengaruh terhadap manajemen laba. Hal ini disebabkan karena tujuan dari perusahaan melakukan pembentukan komite audit hanya sebatas untuk memenuhi pertauran pemerintah. Anggota dari komite audit ini tidak secara 
aktif melaksanakan tugasnya sebagai komite audit sehingga fungsi pengawasan pada perusahaan tidak berjalan dengan baik. Maka hipotesisi ketiga dalam penelitian ini yaitu:

H3: Komite audit berpengaruh negatif terhadap manajemen laba

\section{Pengaruh Pertumbuhan Penjualan terhadap Manajemen Laba}

Pertumbuhan penjualan merupakan sebuah tolak ukur yang memperlihatkan presentase tingkat penjualan dari tahun ke tahun. Tingkat pertumbuhan penjualan dapat memberikan gambaran terkait dengan laba yang juga mengalami peningkatan sehingga terbentuk pola pikir manajer tentang berbagai cara dalam mengoptimalisaikan hasil. Apabila mereka dihadapkan dengan sebuah permasalahan untuk tetap mempertahankan trend laba dan trend penjualan, perusahaan dengan pertumbuhan penjualan yang tinggi cenderung termotivasi untuk melakukan tindakan manajemen laba. Dalam konteks ini, menyebabkan terjadinya konflik keagenan antara principal dan agent. Penelitian Astari dan Suryana (2017) yang memperlihatkan hubungan positif secara signifikan antara pertumbuhan penjualan dengan manajemen laba. Maka hipotesis keempat dalam penelitian yaitu:

H4: Pertumbuhan penjualan berpengaruh positif terhadap manajemen laba

\section{Pengaruh Leverage terhadap Manajemen Laba}

Leverage adalah rasio antara total liabilities dengan total asset. Perusahaan yang mempunyai tingkat rasio leverage yang tinggi berarti mempunyai proporsi hutang yang lebih besar dibandingkan dengan proporsi aset yang dimiliki sehingga perusahaan akan cenderung melakukan tindakan manipulasi dalam bentuk manajemen laba untuk menghindari perjanjian hutang (Saptantinah dalam Yatulhusna, 2015). Maka hipotesis kelima dalam penelitian ini yaitu:

H5: Leverage berpengaruh positif terhadap manajemen laba

\section{METODE PENELITIAN}

Jenis penelitian ini adalah deskritif kuantitatif. Populasi dalam penelitian ini yaitu perusahaan manufaktur seluruh sektor yang terdapat pada Bursa Efek Indonesia (BEI) dengan periode 2015-2019 yang berjumlah 167 perusahaan. Metode yang digunakan dala menentukan sampel penelitian yaitu metode purposive sampling, seperti terlihat pada Tabel 1 . Jenis data yang digunakan di dalam penelitian ini yaitu data sekunder yang berupa laporan keuangan perusahaan manufaktur yang terdaftar di Bursa Efek Indonesia (BEI) tahun 20152019. Data sekunder merupakan data yang didapat secara tidak langsung oleh peneliti. Data yang diperoleh peneliti bersumber dari membaca buku referensi, studi kepustakaan, informasi yang terkait dengan penelitian, serta situs BEI yaitu www.idx.co.id dan www.edusaham.com. Teknik pengumpulan data dalam penelitian ini mneggunakan teknik studi pustaka dan teknik dokumentasi.

Variabel independen di dalam penelitian ini yaitu kepemilikan institusional, komisaris independen, komite audit, pertumbuhan penjualan, dan leverage. Kepemilikan instituional pada penelitian ini di ukur dengan mebandingkan antara jumlah saham institusional dengan jumlah saham beredar dikalikan 100\%. Komisaris independen diukur dengan membandingkan jumlah komisaris independen dengan jumlah seluruh komisaris dikalikan $100 \%$. Untuk komite audit di ukur dengan melihat jumlah komite audit pada perusahaan. Pertumbuhan penjualan di ukur dengan membandingkan antara penjualan tahun sekarang dikurangi penjualan tahun sebelumnya dengan penjualan tahun sebelumnya dikalikan $100 \%$. Selanjutnya untuk leverage di ukur dengan menggunakan Debt Asset Ratio (DAR) dimana membandingkan antara total asset dengan total liabilitas kemudian dikalikan 100\%. Variabel dependen dalam penelitian ini yaitu manajemen laba yang di ukur dengan menggunakan Discretionary Accruals. 
Tabel 1

Kriteria Pemilihan Sampel

\begin{tabular}{llc}
\hline No. & Kriteria & Jumlah \\
\hline $\begin{array}{l}\text { Perusahaan Manufaktur yang terdaftar di Bursa Efek Indonesia (BEI) tahun 2015- } \\
2019\end{array}$ & 167 \\
\hline
\end{tabular}

Perusahaan Manufaktur yang tidak menerbitkan laporan tahunan dan laporan keuangan secara lengkap pada periode 2015-2019 serta tidak mengungkapkan data

2 secara lengkap yang berhubungan dengan variabel penelitian yaitu kepemilikan institusional, komisaris independen, komite audit, pertumbuhan penjualan, dan

leverage.

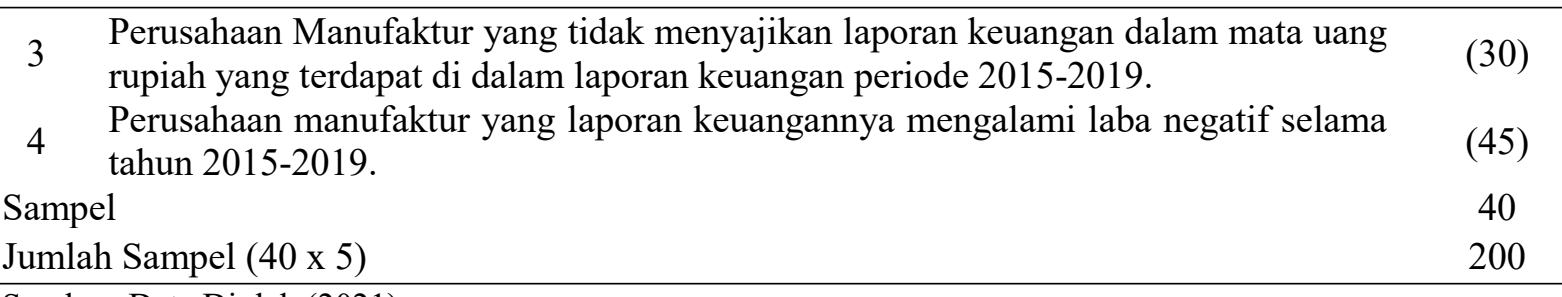

Sumber: Data Diolah (2021)

HASIL DAN PEMBAHASAN

Statistik Deskriptif

Tabel 2

Statitik Deskriptif

\begin{tabular}{|c|c|c|c|c|c|c|}
\hline & & $\mathbf{N}$ & Minimum & Maximum & Mean & Std. Deviation \\
\hline Mnjl & & 200 & -.13838 & .25672 & -.0084595 & .06787442 \\
\hline $\mathrm{KI}$ & & 200 & 5.09752 & 99.41341 & 71.0578616 & 17.97204557 \\
\hline DKI & & 200 & 20.00 & 66.67 & 39.4374 & 8.46074 \\
\hline KA & & 200 & 3 & 4 & 3.09 & .280 \\
\hline PP & & 200 & -.2532 & .3532 & .062752 & .0997509 \\
\hline DAR & & 200 & .0160 & .7320 & 351259 & .1542507 \\
\hline $\begin{array}{l}\text { Valid } \\
\text { (listwise) }\end{array}$ & $\mathrm{N}$ & 200 & & & & \\
\hline
\end{tabular}

Sumber: Hasil Pengolahan Data SPSS 20

Berdasarkan Tabel 2 Variabel Y nya yaitu manajemen laba yang menunjukkan nilai minimum $-0,13838$ dan nilai maksimum 0,25672 dengan rata-rata -0.0084595 dan standar deviasi 0,06787442. Variabel X1 yaitu kepemilikan institusional menunjukkan nilai minimun 5,09752 dan nilai maksimum 99,41341 dengan rata-rata 71.0578616 dan standar deviasi 17,97204557 . Variabel X2 yaitu komisaris independen menunjukkan nilai minimum 20,00 dan nilai maksimum 66,67 dengan rata-rata 39,4374 dan standar deviasi 8,46704.

Variabel X3 yaitu Komite Audit menunjukkan nilai minimum 3 dan nilai maksimum 4 dengan rata-rata 3,09 dan standar deviasi 0,280. Variabel $\mathrm{X} 4$ yaitu pertumbuhan penjualan menunjukkan nilai minimum $-0,2532$ dan nilai maksimum 0,3532 dengan rata-rata 0,062752 dan standar deviasi 0,0997509. Variabel X5 yaitu leverage menunjukkan nilai minimum 
0,0160 dan nilai maksimum 0,7320 dengan nilai rata-rata 0,351259 dengan standar deviasi 0,1542507 .

\section{Uji Normalitas}

Uji normalitas data menggunakan analisis grafik normal probality plot dan uji statistic non-parametik Kolmogrov Smirnov (K-S). Data berdistribusi normal jika hasil dari signifikansi Kolmogorov-Smirnov (K-S) menunjukkan nilai >0,05.

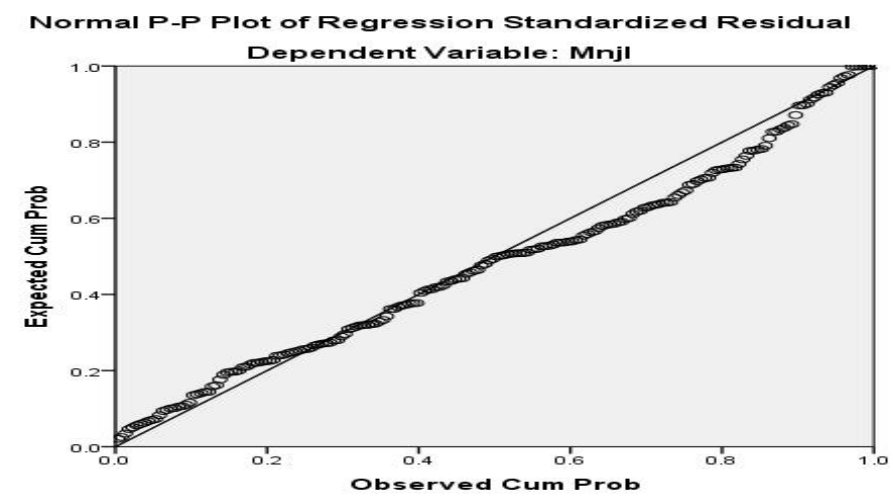

Gambar 1. Grafik Normal probability Plot

Sumber: Data diolah di SPSS v.20

Grafik normal probability plot menunjukkan titik-titik menyebar disekitar garis diagonal dan mengikuti garis diagonal sehingga bisa disimpulkan bahwa data tersebut berdistribusi normal. Untuk lebih memastikan apakah data residual berdistribusi dengan normal atau tidak, maka dilakukan pengujian Kolmogrov Smirnov (K-S).

\section{Tabel 3}

Hasil Uji Kolmogrov Smirnov

\begin{tabular}{llc}
\hline & & Unstandardized Residual \\
\hline $\mathrm{N}$ & & 200 \\
Normal Parameters & Mean & $0 \mathrm{E}-7$ \\
& Std. Deviation & .06595588 \\
& Absolute & .091 \\
Most Extreme Differences & Positive & .091 \\
& Negative & -.047 \\
Kolmogorov-Smirnov Z & & 1.283 \\
Asymp. Sig. (2-tailed) & .074 \\
a. Test distribution is Normal. & \\
b. Calculated from data. & \\
Sumber: Data diolah di SPSS v.20
\end{tabular}

Berdasarkan dari hasil pengujian Komogrov Smirnov (K-S) pada Tabel 3, menunjukkan nilai Asymp. Sig. (2-tailed) atau nilai signifikansi sebesar 0,074 lebih besar dari nilai signifikansi 0,05 . Maka dapat diambil kesimpulan bahwa data berdistribusi secara normal dan model regresi layak untuk digunakan.

\section{Uji Multikolinearitas}

Uji Multikorelasi memiliki tujuan untuk menguji apakah dalam model regresi ditemukan korelasi antar variabel bebas (independen) atau tidak (Widodo, 2018:78). Untuk mengetahui terdapat atau tidaknya multikolinearitas bisa dilihat dari nilai tolerance dan nilai VIF. Uji multikolinearitas dapat dilihat sebagai berikut: 
Tabel 4

Hasil Uji Multikolinearitas

\begin{tabular}{|c|c|c|c|c|c|c|c|c|}
\hline \multirow{2}{*}{\multicolumn{2}{|c|}{ Model }} & \multicolumn{2}{|c|}{$\begin{array}{l}\text { Unstandardized } \\
\text { Coefficients }\end{array}$} & \multirow{2}{*}{$\begin{array}{c}\text { Standardized } \\
\text { Coefficients } \\
\text { Beta }\end{array}$} & \multirow[t]{2}{*}{$\mathrm{t}$} & \multirow[t]{2}{*}{ Sig. } & \multicolumn{2}{|c|}{$\begin{array}{l}\text { CollineariBty } \\
\text { Statistics }\end{array}$} \\
\hline & & B & Std. Error & & & & Tolerance & VIF \\
\hline & (Constant) & -.0403 & .0685 & & -.5893 & .5564 & & \\
\hline \multirow{5}{*}{1} & KI & .0002 & .0003 & .0425 & .5681 & .5706 & .8684 & 1.1515 \\
\hline & DKI & .0014 & .0006 & .1754 & 2.4135 & .0167 & .9220 & 1.0846 \\
\hline & KA & -.0106 & . 0181 & -.0439 & -.5895 & .5562 & .8784 & 1.1384 \\
\hline & PP & .0733 & .0482 & .1077 & 1.5203 & .1301 & .9707 & 1.0302 \\
\hline & DAR & -.0191 & .0323 & -.0434 & -.5908 & .5553 & .9009 & 1.1100 \\
\hline & Dependent V & able: $\mathrm{Mr}$ & & & & & & \\
\hline
\end{tabular}

Sumber: Data Diolah di SPSS v.20

Berdasarkan hasil pengujian dari Tabel 4, dapat dilihat bahwa variabel Kepemilikan Institudional (KI), Dewan Komisaris Independen (DKI), Komite Audit (KA), Pertumbuhan Penjualan (PP), dan Leverage (DAR) mempunyai nilai tolerance diatas $0,10(>0,10)$ dan nilai VIF dibawah $10(<10)$. Maka dapat diambil kesimpulan bahwa tidak terjadi multikolinearitas didalam model regresi antar variabel bebasnya (independen).

\section{Uji Autokorelasi}

Menurut Widodo (2018), Uji Autokorelasi memiliki tujuan untuk menguji apakah didalam model regresi terdapat korelasi antara kesalahan penganggu (residual) pada periode $t$ dengan periode t-1 (sebelumnya). Uji autokorelasi dilakukan dengan uji Durbin-Watson (DW) yang hasilnya sebagai berikut:

\section{Tabel 5}

Hasil Uji Autokorelasi

\begin{tabular}{|c|c|c|c|c|}
\hline Model & R Square & Adjusted R Square & Std. Error of the Estimate & Durbin-Watson \\
\hline 1 & $.236^{\mathrm{a}} .056$ & .031 & .06680042 & 2.039 \\
\hline \multicolumn{5}{|c|}{$\begin{array}{l}\text { a. Predictors: (Constant), DAR, PP, KA, DKI, KI } \\
\text { b. Denendent Variable: Mnil }\end{array}$} \\
\hline
\end{tabular}

Sumber: Data diolah di SPSS v.20

Berdasarkan dari hasil pengujian Tabel 5, dapat dilihat bahwa nilai Durbin-Watson (DW) sebesar 2,039. berdasarkan tabel D-W dengan signifikansi 5\% $\mathrm{n}=200$ dan $\mathrm{k}=5$, diperoleh nilai $\mathrm{dL}=1,7176$ dan $\mathrm{dU}=1,8199$ sedangkan $4-\mathrm{dL}=2,2824$ dan $4-\mathrm{dU}=2,1801$. Karena nilai $\mathrm{D}-$ W diantara dU dan 4-dU $(\mathrm{dU}<\mathrm{d}<4-\mathrm{dU})$ maka dapat diambil kesimpulan bahwa tidak terdapat autokorelasi.

\section{Uji Heteroskedastisitas}

Menurut Widodo (2018:81), Uji Heteroskedatisitas memiliki tujuan untuk menguji apakah di dalam model regresi terjadi ketidaksamaan variance dari residual satu pengamatan ke pengamatan lain. 


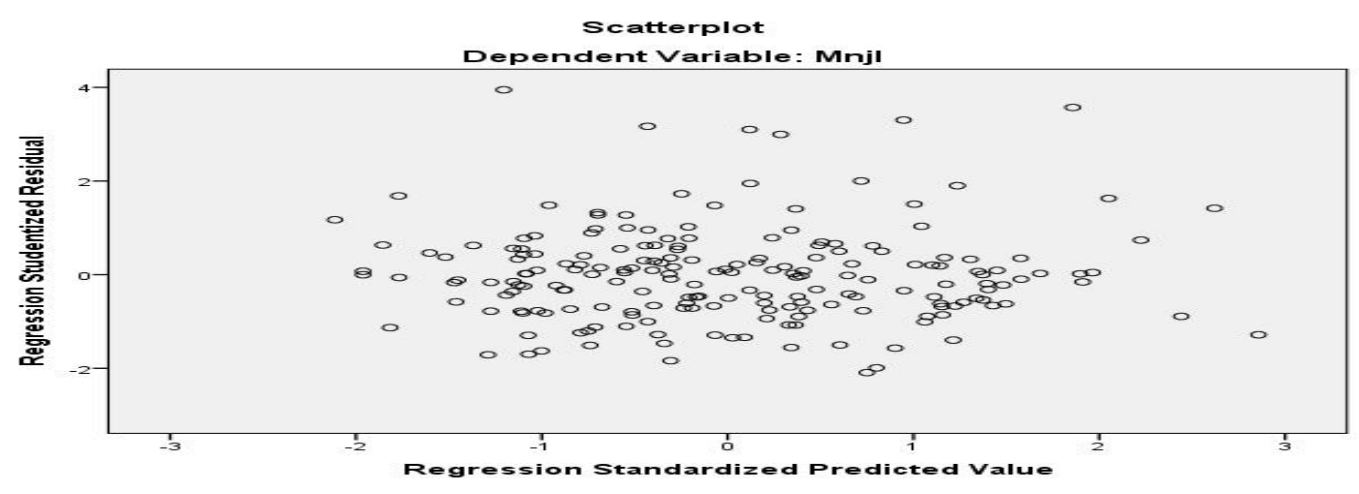

Gambar 2. Diagram Scatterplot

Sumber: Data diolah di SPSS v.20

Dari grafik scatterplot diatas dapat dilihat bahwa titik-titik menyebar secara acak dan juga tersebar diatas maupun dibawah angka 0 dan sumbu Y. Hal ini menunjukkan bahwa didalam model regresi tidak terjadi heteroskedastisitas.

\section{Analisis Regresi Linear Berganda}

Analisis regresi linear berganda digunakan dalam menganalisis seberapa besar pengaruh variabel-variabel independen terhadap variabel dependen. Berdasarkan dari uji asumsi klasik yang sudah dilakukan, maka bisa disimpulkan bahwa model regresi linear berganda yang digunakan berdistribusi normal. Hasil dari analsisi regresi linear berganda diperoleh mengunakan SPSS v.20 terdapat pada Tabel 6, Maka dapat dilihat persamaan regresi linear berganda yang terbentuk sebagai berikut:

$$
\begin{gathered}
\mathrm{Mnjl}=-0,0403+0,0002(\mathrm{KI})+0,0014(\mathrm{DKI})-0,0106(\mathrm{KA})+0,0733(\mathrm{PP})-0,0191(\mathrm{DAR}) \\
+\varepsilon
\end{gathered}
$$

Adapun implementasi dari persamaan tersebut adalah sebagai berikut:

a. Nilai konstanta (a) sebesar -0,0403 menunjukkan bahwa jika tidak ada variabel independen (kepemilikan institusional, komisaris independen, komite audit, pertumbuhan penjualan, dan leverage) maka tingkat manajemen laba perusahaan manufaktur di BEI sebesar -0,0403.

b. Koefisien regresi kepemilikan institusional (KI) sebesar 0,0002 menunjukkan bahwa apabila setiap kenaikan KI sebesar 1 (satu) satuan dengan asumsi variabel independen lainnya dianggap konstan, maka manajemen laba mengalami kenaikan sebesar 0,002..

c. Koefisien regresi komisaris independen (DKI) sebesar 0,0014 menunjukkan bahwa apabila DKI mengalami kenaikan 1 (satu) satuan dengan asumsi variabel independen lainnya dianggap konstan, maka manajemen laba mengalami kenaikan sebesar 0,0014.

d. Koefisien regresi komite audit (KA) sebesar -0,0106 menujukkan bahwa apabila KA mengalami kenaikan 1 (satu) satuan dengan asumsi variabel independen dianggap konstan, maka manajemen laba mengalami penurunan sebesar 0,0106 .

e. Koefisien regresi pertumbuhan penjualan (PP) sebesar 0,0733 menunjukkan bahwa apabila PP mengalami kenaikan 1 (satu) satuan dengan asumsi variabel independen lainnya dianggap konstan, maka manajemen laba mengalami kenaikan sebesar 0,0733.

f. Koefisien regresi leverage (DAR) sebesar -0,0191 menujukkan bahwa apabila DAR mengalami kenaikan 1 (satu) satuan dengan asumsi variabel independen dianggap konstan, maka manajemen laba mengalami penurunan sebesar 0,0191. 


\section{Uji Parsial (Uji Statistik t)}

Uji parsial memperlihatkan seberapa jauh pengaruh satu variabel bebas secara individual terhadap variabel terikat (Ghozali, 2016). Hasil uji t yang terdapat pada penelitian ini dapat dilihat sebagai berikut:

\section{Tabel 6}

Hasil Uji Statistik t

\begin{tabular}{|c|c|c|c|c|c|c|}
\hline \multirow{2}{*}{\multicolumn{2}{|c|}{ Model }} & \multicolumn{2}{|c|}{ Unstandardized Coefficients } & \multirow{2}{*}{$\begin{array}{c}\text { Standardized Coefficients } \\
\text { Beta }\end{array}$} & \multirow{2}{*}{$\mathrm{T}$} & \multirow{2}{*}{ Sig. } \\
\hline & & $\mathrm{B}$ & Std. Error & & & \\
\hline \multirow{6}{*}{1} & (Constant) & -.0403 & .0685 & & -.5893 & .5564 \\
\hline & KI & .0002 & .0003 & .0425 & .5681 & .5706 \\
\hline & DKI & .0014 & .0006 & .1754 & 2.4135 & .0167 \\
\hline & KA & -.0106 & .0181 & -.0439 & -.5895 & .5562 \\
\hline & PP & .0733 & .0482 & .1077 & 1.5203 & .1301 \\
\hline & DAR & -.0191 & .0323 & -.0434 & -.5908 & .5553 \\
\hline
\end{tabular}

Sumber: Data diolah di SPSS v.20

Berdasarkan hasil pengujian statistik t pada Tabel 6 , hasil pengujian menunjukkan nilai signifikansi sebesar 0,5706, nilai tersebut lebih besar dari 0,05 atau 0,5706 $>0,05$ maka Ho diterima $\mathrm{H}_{1}$ ditolak. Maka bisa diambil kesimpulan bahwa secara parsial variabel kepemilikan institusional tidak berpengaruh terhadap manajemen laba. H1 ditolak. Berdasarkan tabel di atas hasil pengujian menunjukkan nilai signifikansi sebesar 0,0167 , nilai tersebut lebih kecil dari 0,05 atau $0,0167<0,05$ maka Ho ditolak $\mathrm{H}_{1}$ diterima. Nilai t positif menujukkan bahwa komisaris independen memiliki hubungan yang searah dengan manajemen laba. Maka bisa diambil kesimpulan bahwa secara parsial komisaris independen berpengaruh signifikan terhadap manajemen laba. $\mathrm{H} 2$ ditolak.

Berdasarkan tabel di atas hasil pengujian menunjukkan nilai signifikansi sebesar 0,5562, nilai tersebut lebih besar dari 0,05 atau $0,5562>0,05$ maka Ho diterima $\mathrm{H}_{1}$ ditolak. Maka dapat diambil kesimpulan bahwa secara parsial variabel komite audit tidak berpengaruh terhadap manajemen laba. $\mathrm{H} 3$ ditolak. Berdasarkan tabel di atasa hasil pengujian menunjukan nilai signifikan sebesar 0,1301, nilai tersebut lebih besar dari 0,05 atau 0,1301 > 0,05 maka Ho diterima $\mathrm{H}_{1}$ ditolak. Maka dapat diambil kesimpulan bahwa secara parsial pertumbuhan penjualan tidak berpengaruh terhadap manajemen laba. H4 ditolak. Berdasarkan tabel di atas hasil pengujian menunjukkan nilai signifikansi sebesar 0,5553, nilai tersebut besar dari 0,05 atau 0,5553 >0,05 maka Ho diterima $\mathrm{H}_{1}$ ditolak. Maka bisa diambil kesimpulan bahwa secara parsial leverage tidak berpengaruh terhadap manajemen laba. H5 ditolak.

\section{Uji Simultan (Uji Statistik F)}

Uji simultan memiliki tujuan untuk mengetahui apakah variabel bebas (independen) secara bersama-sama memiliki pengaruh terhadap manajemen laba (Ghozila, 2016). Hasil uji t yang terdapat pada penelitian ini dapat dilihat sebagai berikut:

Tabel 7

Hasil Uji Statistik F

\begin{tabular}{llllll}
\hline \multicolumn{1}{c}{ Model } & Sum of Squares & Df & Mean Square & F & Sig. \\
\hline Regression & .051 & 5 & .010 & 2.290 & $.047^{\mathrm{b}}$ \\
1 Residual & .866 & 194 & .004 & & \\
Total & .917 & 199 & & & \\
a. Dependent Variable: Mnjl & & & & \\
\hline b. Predictors: (Constant), DAR, PP, KA, DKI, KI &
\end{tabular}


Berdasarkan hasil data pada Tabel 7, diperoleh nilai signifikansi sebesar 0,047, nilai tersebut lebih kecil dari 0,05 atau 0,047 <0,05 maka Ho ditolak $\mathrm{H}_{1}$ diterima. Oleh karena itu bisa disimpulkan variabel kepemilikan institusional, komisaris independen, komite audit, pertumbuhan penjualan, dan leverage secara simultan berpengaruh signifikan terhadap manajemen laba.

\section{Uji Koefisien Determinasi (Adjusted $\mathbf{R}^{\mathbf{2}}$ )}

Koefisien Determinasi $\left(\mathrm{R}^{2}\right)$ digunakan untuk mengukur seberapa jauah kemampuan variabel independen dalam menerangkan variabel dependen. Uji koefisien determinasi bisa dilihat dari ukuran adjusted $\mathrm{R}^{2}$. Berikut adalah hasil koefisien determinasi:

Tabel 8

Koefisien Determinasi ( Adjusted $\mathbf{R}^{2}$ )

\begin{tabular}{lcccc}
\hline Model $\quad \mathrm{R}$ & $\mathrm{R}$ Square & Adjusted R Square & Std. Error of the Estimate & Durbin-Watson \\
\hline $1 \quad .236^{\mathrm{a}} .056$ & .031 & .06680042 & 2.039 \\
a. Predictors: (Constant), DAR, PP, KA, DKI, KI & \\
\hline b. Dependent Variable: Mnjl & \\
Sumber: Data diolah di SPSS v.20
\end{tabular}

Berdasarkan tabel diatas, maka diperoleh hasil sebesar 0,031 atau 3,1\%. Angka tersebut menjelaskan bahwa variabel dependen mampu diprediksi oleh variabel independen hanya sebesar 3,1\% sementara sisanya 96,9\% dipengaruhi oleh variabel lain yang tidak diteliti didalam penelitian ini. Hal ini menunjukkan bahwa masih ada faktor lain diluar kepemilikan institusional, komisaris indpenden, komite audit, pertumubuhan penjualan, dan leverage yang berpengaruh terhadap manajemen laba.

\section{Pengaruh Kepemilikan Institusional terhadap Manajemen Laba}

Berdasarkan dari hasil pengujian yang telah dilakukan menunjukkan bahwa variabel kepemilikan institusional tidak memiliki pengaruh terhadap manajemen laba. Hal ini disebabkan karena kepemilikan institusional yang dikatakan sebagai pemilik sementara perusahaan lebih terfokus pada current earnings, sehingga walaupun jumlah kepemilikan institusional ini meningkat atau menurun mereka akan tetap cenderung terlibat didalam tindakan manajemen laba. Hasil penelitian mendukung penelitian dari Almalita (2017) yang menyatakan bahwa kepemilikian institusional tidak memiliki pengaruh terhadap manajemen laba.

\section{Pengaruh Komisaris Independen terhadap Manajemen Laba}

Berdasarkan dari hasil pengujian yang telah dilakukan dapat dinyatakan bahwa dewan komisaris independen berpengaruh terhadap manajemen laba. Variabel dewan komisaris independen memiliki hubungan positif (searah) dengan manajemen laba. Hal ini disebabkan karena dewan komisaris independen di dalam perusahaan mempunyai tugas serta tanggungjawab terhadap pengawasan informasi yang terdapat didalam laporan keuangan. Dewan komisaris independen secara umum memiliki pengawasan yang lebih baik terhadap manajer perusahaan sehingga dapat mempengaruhi kemungkinan terjadinya penyimpangan didalam menyajikan laporan keuangan yang dilakukan oleh manajer perusahaan. Fungsi dewan sebagai pengawas manajemen bisa terlihat dari setiap agenda rapat yang dilakukan oleh dewan dan berkaitan dengan pengendalian manajemen yang lebih berkualitas. Hasil penelitian ini sejalan dengan penelitian Anggraeni \& Hadiprajitno (2013) yang menyatakan bahwa dewan komisaris independen berpengaruh positif terhadap manajemen laba karena dewan komisaris independen 


\section{Pengaruh Komite Audit terhadap Manajemen Laba}

Berdasarkan dari hasil pengujian yang telah dilakukan dapat dinyatakan bahwa variabel komite audit tidak berpengaruh terhadap manajemen laba. Hal ini disebabkan karena tujuan perusahaan untuk melakukan pembentukan komite audit hanya sekedar untuk memenuhi peraturan OJK yang berdasarkan mandatory, sehingga besar ataupun kecilnya jumlah dari komite audit didalam perusahaan tidak dapat membatasi terjadinya praktik manajemen laba. Hasil penelitian ini sejalan dengan Almalita (2017) yang menyatakan bahwa komite audit tidak memiliki pengaruh terhadap manajemen laba.

\section{Pengaruh Pertumbuhan Penjualan terhadap manajemen Laba}

Berdasarkan dari hasil pengujian yang telah dilakukan dapat dinyatakan bahwa pertumbuhan penjulan tidak berpengaruh terhadap manajemen laba. Hal ini disebabkan karena manajer tidak perlu untuk meninggikan hasil dari penjualan ataupun laba yang telah diperoleh perusahaan, dan perusahaan juga tidak perlu untuk memalsukan hasil kinerjanya. Apabila pertumbuhan penjualan semakin tinggi, manajer semakin tidak termotivatisi untuk melakukan tindakan manajemen laba. Hasil penelitian ini sejalan dengan penelitian Melinda dan Widyasari (2019) yang menyatakan bahwa pertumbuhan penjualan tidak memiliki pengaruh terhadap manajemen laba.

\section{Pengaruh Leverage terhadap Manajemen Laba}

Berdasarkan dari hasil pengujian yang telah dilakukan dapat dinyatakan bahwa leverage tidak berpengaruh terhadap manajemen laba. Hal ini disebabkan karena besarnya leverage pada perusahaan akan memperkecil ruang gerak manajemen dalam melakukan tindakan manajemen laba hal ini dikarenakan adanya pengawasan dari pihak kreditor. Perusahaan yang memiliki tingkat leverage yang cukup tinggi akan menghadapi resiko default yang tinggi yaitu perusahaan terancam tidak mampu dalam memenuhi kewajibannya. Hasil penelitian ini didukung oleh penelitian Kurniawati (2018) yang menyatakan bahwa leverage tidak memiliki pengaruh terhadap manajemen laba.

\section{SIMPULAN, KETERBATASAN DAN SARAN Simpulan}

Hasil analisis data dan pembahasan mengenai kepemilikan institusional, komisaris independen, komite audit, pertumbuhan penjualan, dan leverage, maka dapat disimpulkan sebagai berikut: Kepemilikan Intitusional tidak berpengaruh terhadap manajemen laba. Hal ini menujukkan bahwa walaupun jumlah dari kepemilikan institusional meningkat ataupun menurun mereka akan tetap cenderung terlibat didalam tindakan manajemen laba yang dilakukan oleh perusahaan.Komisaris independen berpengaruh terhadap manajemen laba. Hal ini menujukkan bahwa secara umum dewan komisaris independen memiliki pengawasan yang lebih baik terhadap manajer perusahaan sehingga dapat mempengaruhi kemungkinan terjadinya penyimpangan didalam menyajikan laporan keuangan yang dilakukan oleh manajer perusahaan.

Komite audit tidak berpengaruh terhadap manajemen laba. Hal ini disebabkan karena tujuan perusahaan untuk melakukan pembentukan komite audit hanya sekedar untuk memenuhi peraturan OJK yang berdasarkan mandatory, sehingga besar ataupun kecilnya jumlah dari komite audit didalam perusahaan tidak dapat membatasi terjadinya praktik manajemen laba. Terkait dengan keberadaan komite audit dan wewenang yang dimiliki oleh komite audit hanya sebatas memberi pendapat tetapi keputusan akhir tetap pada pimpinan perusahaan. Pertumbuhan penjualan tidak berpengaruh terhadap manajemen laba. Hal ini disebabkan karena manajer tidak perlu untuk meninggikan hasil dari penjualan ataupun laba yang telah diperoleh perusahaan, dan perusahaan juga tidak perlu untuk memalsukan hasil 
kinerjanya. Apabila pertumbuhan penjualan semakin tinggi, maka manajer semakin tidak termotivatisi untuk melakukan tindakan manajemen laba. Leverage tidak berpengaruh terhadap manajemen laba. Hal ini disebabkan karena besarnya leverage pada perusahaan akan memperkecil ruang gerak manajemen dalam melakukan tindakan manajemen laba hal ini dikarenakan adanya pengawasan dari pihak kreditor. Perusahaan yang memiliki tingkat leverage yang cukup tinggi akan menghadapi resiko default yang tinggi yaitu perusahaan terancam tidak mampu dalam memenuhi kewajibannya. Tindakan manajemen laba ini tidak dapat membantu perusahaan dalam mengatasi hutang yang cukup tinggi dalam kemungkinan default. Pembayaran terhadap hutang harus tetap dilakukan dan tidak dapat untuk dihindari dengan melakukan tindakan manajemen laba.

\section{Saran}

1. Pada penelitian selanjutnya disarankan untuk meneliti lebih dalam lagi terkait dengan faktor-faktor apa saja yang dapat mempengaruhi manjemen laba dengan menggunakan variabel indepnden yang lain atau diluar penelitian ini.

2. Pada penelitian selanjutnya disarankan untuk tidak hanya menggunakan sampel perusahaan manufaktur yang terdaftar di BEI dan peneliti selanjutnya bisa mempeluas penggunaan sampel dengan menggunakan perusahaan diluar perusahaan manufaktur (jasa, perbankan, dll).

3. Pada penelitian selanjutnya diharapkan mampu menggunakan model lain atau proksi lain dalam mendeteksi manajemen laba selain model Jones.

\section{DAFTAR PUSTAKA}

Almalita, Y. (2017). Pengaruh Corporate Governance Dan Faktor Lainnya Terhadap Manajemen Laba. Jurnal Bisnis Dan Akuntansi, 19, (2), 183-194.

Anindya, W., \& Yuyetta, E.N.A. (2020). Pengaruh Leverage, Sales Growth, Ukuran Perusahaan, Dan Profitabilitas Terhadap Manajemen Laba. Diponegoro Journal Of Accounting, 9, (3), 1-14.

Anggraeni, R. M., \& Hadiprajitno, P. B. (2013). Pengaruh Struktur Kepemilikan Manajerial, Ukuran Perusahaan, Dan Praktik Corporate Governance Terhadap Manajemen Laba. Diponegoro Journal Of Accounting, 2, (3), 1-13.

Annisa, A. A., \& Hapsoro, D. (2017). Pengaruh Kualitas Audit, Leverage, Dan Growth Terhadap Praktik Manajemen Laba. Jurnal Akuntansi, 5, (2), 99-110.

Astari, A. A., \& Suryana, K. (2017). Faktor-Faktor Yang Mempengaruhi Manajemen Laba. E-Jurnal Akuntansi Universitas Udayana, 20, (1), 290-319.

Bangun, W.V.B. (2017). Analisis Pengaruh Kepemilikan Manajerial, Komposisi Komite Audit, Kualitas Audit, Ukuran Perusahaan Dan Profitabilitas Terhadap Manajemen Laba Pada Perusahaan Manufaktur Yang Terdaftar di BEI Tahun 2013-2016. Skripsi. Universitas Sumatera Utara.

Basuki, A. T., \& Nano, P. (2016). Analisis Regresi Dalam Penelitian Ekonomi Dan Bisnis. Jakarta: PT Rajagrafindo Indonesia.

Cahyaningtyas, E.D. (2018). Pengaruh Komite Audit, Ukuran Perusahaan, Kepemilikan Manajerial, Kepemilikan Institusional, Perencanaan Pajak, Dewan Komisaris Independen Dan Kualitas Audit Terhadap Manajemen Laba (Studi Empiris Pada Perusahaan Manufaktur Yang Terdaftar Di Bei Periode 2014-2016). Skripsi. Universitas Muhammadiyah Surakarta.

Effendi, M. A. (2016). The Power of Good Corporate Governance. Jakarta: Salemba Empat. Fahmi, I. (2014). Analisis Laporan Keuangan. Bandung: Alfabeta. 
Ghozali, I. (2016). Aplikasi Analisis Multivariate dengan Program IBM SPSS 23. Semarang: BPFE Universitas Diponegoro.

Hermanto, W. (2015). Pengaruh Kepemilikan Institusional, Ukuran Perusahaan, Leverage Terhadap Manajemen Laba. Skripsi. Universitas Muhammadiyah Surakarta.

Ikatan akuntansi Indonesia. (2015). Standar akuntansi keuangan. Jakarta: Salemba Empat.

Ita, V. (2017). Hubungan Kompensasi Bonus Dengan Manajemen Laba. Skripsi. Universitas Sanata Dharma.

Kadir, N. A. (2018). Pengaruh Ukuran Perusahaan Dan Sales Growth Terhadap Manajemen Laba Dengan Tax Avoidence Sebagai Variabel Intervening. Skripsi. Universitas Islam Negeri Alauddin Makassar.

Kasmir. (2016). Analisis Laporan Keuangan. Jakarta: PT Raja Grafindo Persada.

Kasmir. (2017). Analisis Laporan Keuangan. Jakarta: PT Raja Grafindo Persada.

Kurniawati, D.A. (2018). Analisis Pengaruh Leverage, Ukuran Perusahaan, Komite Audit, Dan Profitabilitas Terhadap Manajemen Laba (Studi Empiris Perusahaan Manufaktur Yang Terdaftar di BEI Periode 2014-2016). Skripsi,Universitas Muhammadiyah Surakarta

Mahariana, D. G., \& Ramantha, W. (2014). Pengaruh Kepemilikan Manajerial Dan Kepemilikan Institusional Pada Manajemen Laba Perusahaan Manufaktur Di Bursa Efek Indonesia. E-Jurnal Akuntansi Universitas Udayana, 7, (2), 519-528.

Melinda \& Widyasari. (2019). Faktor Yang Mempengaruhi Manajemen Laba Perusahaan Manufaktur Yang Terdaftar di BEI. Jurnal Multiparadigma Akuntansi, 1, (2), 452259.

Novianus. (2016). Hubungan Antara Ukuran Perusahaan, Leverage, Profitabilitas dengan Manajemen Laba. Skripsi. Universitas Sanata Dharma.

Purnama, D. (2017). Pengaruh Profitabilitas, Leverage, Ukuran Perusahaan, Kepemilikan Institusional, Dan Kepemilikan Manajerial Terhadap Manajemen Laba. JRKA, 3, (1), $1-14$.

Sari, S. Y., \& Rusli. (2015). Anaisis Faktor-Faktor Yang Mempengaruhi Manajemen Laba Pada Perusahaan Manufaktur Yang Terdaftar Di Bursa Efek Indonesia. Jom FEKON, 2, (2), 1-15.

Scott, W. R. (2015). Financial Accounting Theory. Sevent Edition. Canada: Library and Archives Canada Cataloguing.

Sugiyono. (2017). Metode Penelitian Kuantitatif, Kualitatif, Dan R\&D. Bandung: Alfabeta.

Sulisyanto, H. S. (2018). Manajemen Laba: Teori dan Model Empiris. Jakarta: PT Grasindo.

Sumbramanyam, K. R., \& John, J. W. (2014). Analisis LAporan Keuangan (Edisi 10, Buku 1). Jakarta: Salemba Empat.

Taco, C., \& Ilat, V. (2016). Pengaruh Earning Power, Komisaris Independen, Dewan Direksi, Komite Audit Dan Ukuran Perusahaan Terhadap Manajemen Laba Pada Perusahaan Manufaktur Yang Terdaftar Di Bursa Efek Indonesia. Jurnal EMBA, 4, (4), 873-884.

Trimurti, F. (2019). Pengaruh Kepemilikan Manajerial, Ukuran Perusahaan, Dewan Komisaris Independen dan Profitabilitas Terhadap Manajemen Laba. Skripsi. Institut Bisnis dan Informatika Kosgoro 1957.

Turot, M. (2019). Pengaruh Kebijakan Dividen, Corporate Governance, Free Cash Flow, Dan Pertumbuhan Penjualan Terhadap Manajemen Laba. Jurnal AKRAB JUARA, 4, (4), 19-27.

Utami, N. (2016). Pengaruh Leverage, Kepemilikan Institusional, Dan Kepemilikan Manajerial Terhadap Manajemen Laba. Skripsi. Universitas Sanata Dharma.

Widodo, D. (2018). Metodologi Penelitian. Depok: PT Raja Grafindo Persada.

Widyaningsih, H. (2017). Pengaruh Corporate Governance Terhadap Manajemen Laba. Jurnal Nominal, 6, (2), 91-107. 
Yatulhusna, N. (2015). Pengaruh Profitabilitas, Leverage, Umur, Dan Ukuran Perusahaan Terhadap Manajemen Laba. Skripsi. Universitas Islam Negeri Syarif Hidayatullah.

http://money.cnn.com

www.idx.co.id

www.edusaham.com 